Int. J. Dev. Biol. 56: 949-958 (2012)

doi: 10.1387/ijdb.120144jp

\title{
The fate of granulosa cells following premature oocyte loss and the development of ovarian cancers
}

\author{
JANET L. PITMAN*,1, ALAN S. MCNEILLY², JUDY R. MCNEILLY², LAURA E. HAYS ${ }^{3}$, \\ GROVER C. BAGBY JR. ${ }^{3}$, HEYWOOD R. SAWYER ${ }^{4}$ and KENNETH P. MCNATTY ${ }^{1}$ \\ ${ }^{1}$ School of Biological Sciences, Victoria University of Wellington, Wellington, New Zealand, \\ ${ }^{2}$ MRC Centre for Reproductive Health, The Queen's Medical Research Institute, University of Edinburgh, Edinburgh, UK, \\ ${ }^{3}$ Knight Cancer Institute, Oregon Health \& Science University, Portland, OR, USA and \\ ${ }^{4}$ School of Pharmacy, University of Wyoming, Laramie, WY, USA
}

\begin{abstract}
This review examines the importance of the epithelial origin of granulosa cells and their possible contribution to the development of ovarian cancers in three animal models. We hypothesise that undifferentiated granulosa cells, devoid of their germ cell regulator, retain their embryonic plasticity and may give rise to ovarian cancers of epithelial origin. Dazl-KO and FancD2-KO mice and BMP15-KO sheep are animal models in which germ cells or oocytes are lost at specific stages of follicular formation or growth, leaving behind clusters of residual, but healthy somatic cells. A common feature in Dazl-and Fancd2-KO animals following germ cell/oocyte loss is the presence of sex cords and intraovarian epithelial ducts or tubules. In Dazl-KO mice, cord/tubule-like structures, OSE invaginations and clusters of steroidogenic cells became increasingly prominent with age, but these abnormal structures remained benign. In Fancd2-KO mice, the formation of sex-cords and intraovarian tubules lead to the formation of tumours with multiple phenotypes including luteomas, papillary cysts and malignant carcinomas (e.g. adenocarcinomas). In BMP15-KO sheep, oocytes die as follicles start to grow, leaving 'nodules' containing granulosa cells with a capacity to respond to follicle stimulating hormone and synthesize inhibin. Thereafter, these nodules coalesced and a range of benign solid or semi-solid tumour phenotypes developed. We conclude that premature loss of oocytes, but not granulosa cells, leads to tumour formation with multiple phenotypes. Moreover, the severity of tumour development is linked to both the specificity of the mutation and the timing of oocyte loss relative to that of follicular formation.
\end{abstract}

KEY WORDS: germ cell, sex cord, intraovarian tubule, tumor, epithelium.

\section{Introduction}

Ovarian cancers (OC) present as a remarkably diverse array of tumour phenotypes. Although the initiating events, specific cell lineages and genes that lead to the progression of neoplastic cells to these phenotypes remains to be fully elucidated, the consensus view is that $O C$ is not a single disease and unlikely to be due to a single causal event (Vaughan et al., 2011). Moreover, the evidence suggests some aggressive $\mathrm{OC}$ of epithelial origin do not originate in ovarian tissues (Auersperg 2011; Kurman \& Shih, 2010; Vaughan et al., 2011; Kim et al., 2012). Nevertheless, gene expression profiling of human ovaries and reported outcomes from genetically mutant mouse models, suggest that the ovarian surface epithelium (OSE) is also likely to be a source of OC (Vanderhyden 2005; Bowen et al., 2009; Mullany et al., 2011). What is often overlooked is the evidence that in some species, (e.g. sheep and mice), significant proportions of granulosa cells in primordial follicles are recruited from the OSE during fetal or early neonatal life (Sawyer et al., 2002; Mork et al., 2012). However, it is unclear as to whether the epithelial-derived granulosa cells in ovarian follicles ever contribute to ovarian pathologies with abnormal epithelial phenotypes.

It is well-known that chemical or X-irradiation treatments or ovarian transplantation can all lead to premature oocyte loss and are followed by the formation of OC with mixed tumour phenotypes:

Abbreviations used in this paper: BMP, bone morphogenetic protein; Dazl, deleted in azoospermia-like; Fancd2, Fanconi anemia complementation group D2; FSH, follicle stimulating hormone; $\mathrm{KO}$, knockout; OC, ovarian cancer.

\footnotetext{
*Address correspondence to: Janet L. Pitman. School of Biological Sciences, Victoria University of Wellington, Wellington, New Zealand 6140. Tel: +64-4-463-7450. Fax +64-4-463-5331 e-mail: janet.pitman@vuw.ac.nz
} 


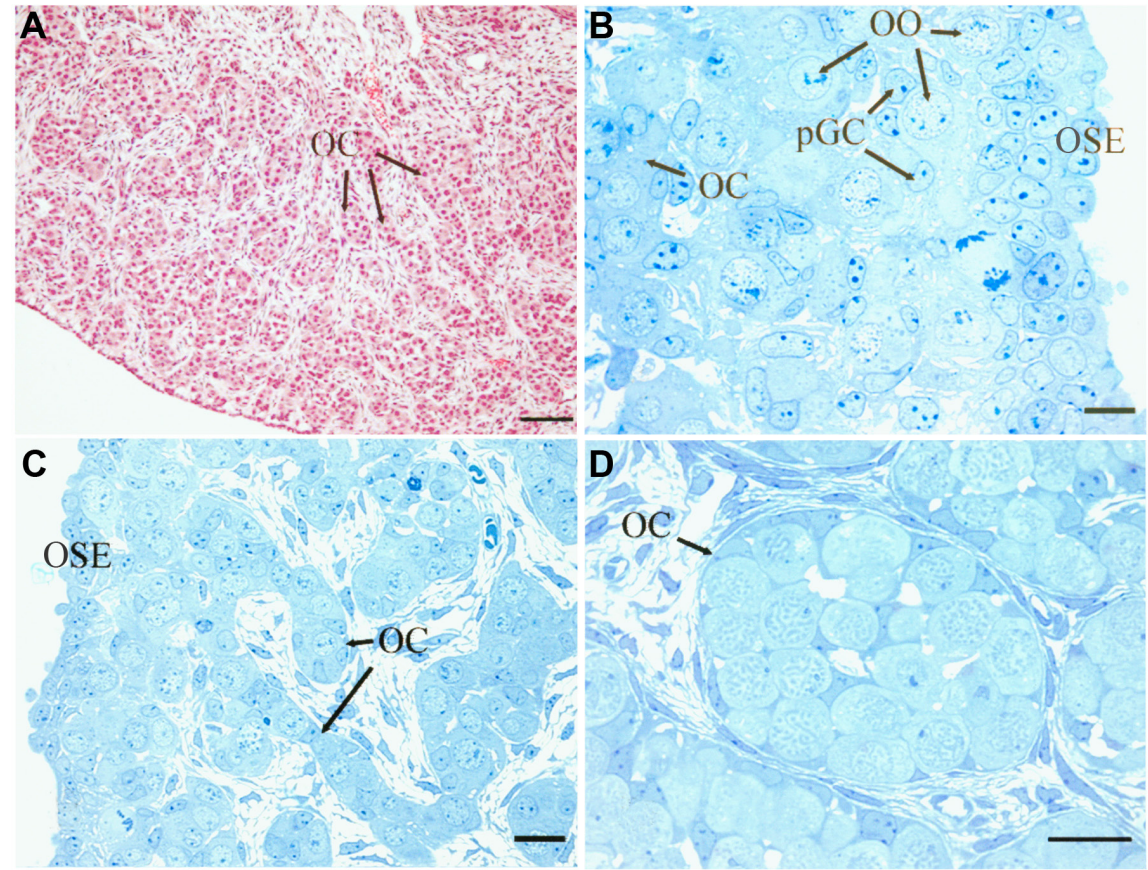

Fig. 1. Histoarchitecture of ovine fetal ovaries at days $55(A, B)$ and $75(C, D)$ of gestation highlighting the ovarian surface epithelium (OSE), ovigerous cords (OC), oogonia (OO) and pregranulosa cells (pGC). (A) Extensive arrays of ovigerous cords isolate germ cells and pGC from surrounding stroma (bar, $80 \mu \mathrm{m})$. (B) Note the multiple layers of OSE immediately adjacent to $O O$ within the OC (bar, $20 \mu \mathrm{m})$. (C) OC were open to, and continuous with the OSE through Day 75 (bar, $5 \mu \mathrm{m})$, and (D) cross-section through an OC with preGC interspersed amongst oocytes that have initiated meiosis (bar, $20 \mu \mathrm{m})$. This figure was reproduced from Sawyer et al. (2002) with permission from Biol. Reprod.

the most common of those reported being granulosa cell tumours (Howell et al., 1954; Guthrie 1958; Krarup 1970). Additionally, tumours such as those referred to as sex cord tumours are also considered to be of granulosa cell origin (Fuller et al., 2002). In animal models in which the oocyte growth factors, bone morphogenetic protein 15 (BMP15) or growth differentiation factor 9 (GDF9) are inactivated or where the biological activity of these factors is modified, ovarian follicular development is severely compromised soon after the initiation of growth (Braw-Tal et al., 1993; Dong et al., 1996; Juengel et al., 2000, 2002a; Hanrahan et al., 2004; Nicol et al., 2009). Thereafter, the oocytes but not the granulosa cells degenerate resulting in a variable range of abnormal phenotypes. While oocytes have a profound regulatory influence on granulosa cell proliferation (Gilchrist et al., 2001; Eppig 2001), surviving granulosa cells following the premature loss of oocytes still retain an ability to proliferate and/or to transform into cord-like, solid (e.g. luteal like) or cyst-like structures (Braw-Tal et al., 1993, Wu et al., 2004).

Using three animal models in which oocytes are lost prematurely, this review will address the hypothesis that granulosa cells of epithelial origin retain their plasticity and in some cases, when devoid of their germ cell regulator, grow in an uncontrolled manner to form tumours with multiple phenotypes. In the deleted in azoospermia-like (Dazl) knockout (KO) mouse model, germ cells become associated with somatic cells of presumed epithelial origin within ovigerous cords before birth. However in the first few days after birth, all oogonia/oocytes die leaving behind the associated epithelial cells. Thereafter, these oocyte-deficient ovaries undergo abnormal transformational changes (McNeilly et al., 2000). In the case of Fanconi anemia complementation group D2 (Fancd2) KO mice, some primordial follicles form and start to grow but by three months of age all oocytes have died and the surviving granulosa cells often become reorganised into sex cords. Over time these give rise to ovarian tumours often characterized by epithelial and malignant phenotypes (Houghtaling et al., 2003). In the homozygous BMP15-mutant sheep, granulosa cells become associated with oocytes to form primordial follicles, but oocytes die once follicle growth is initiated leading to the formation of ovarian tumour-like structures (BrawTal et al., 1993).

Aconsistent and important observation is that following the loss of oocytes, residual granulosa cells persist in nodules, or develop into cords and/or tubules. This predisposition for epithelialderived cells that were previously associated with oocytes in primordial follicles to form cords, or intraovarian ducts, may be indicative of an undifferentiated cell-type that has retained its fetal origins and plasticity (van Wagenen \& Simpson 1965; Sawyer et al., 2002; Mork et al., 2012). For the purposes of this review the process of primordial follicle formation, using sheep as the principal animal model, will be described. Comparisons to primordial follicle formation in the mouse and human will be made. In addition, the fate of germ cell-associated epithelial/granulosa cells in Dazl-KO and Fancd2-KO mice, and the homozygous mutant BMP15 sheep model will be described. In the Dazl-KO model, somatic cells make contact with germ cells before birth, but follicles fail to form in early post-natal life after premature loss of oocytes. In the Fancd2-KO mice, primordial follicles form but oocytes die within the first month(s) of neonatal life. In the homozygous BMP15-mutant sheep model primordial follicles form normally, but oocytes are lost once follicular growth is initiated. In all three of the models considered herein, oocyte loss is followed by a progressive series of abnormal morphological transformations involving germ cell associated cells or epithelial-derived granulosa cells that lead to tumours with multiple phenotypes.

\section{Ovarian follicular assembly}

The sequence of morphological events leading to ovarian follicular formation in sheep has been described in detail (Sawyer et al., 2002; Juengel et al., 2002b). By the time of gonadal sex differentiation (Days 30-35 of fetal life), most germ cells (as assessed by $c$-kit mRNA localisation and morphology) were localised to the ovarian cortex (McNatty et al., 2000; Sawyer et al., 2002) with some closely associated with the OSE. Around day 38 of fetal life, many germ cells in the cortex were in direct physical contact with at least one somatic "pregranulosa" cell. These fusiform-shaped mesenchymal cells have long cytoplasmic processes (Sawyer et al., 2002) and express kit ligand (McNatty et al., 2000). The sequence of events leading to follicular formation is described in Figs 1,2. After Day 38 , the pregranulosa cell-oogonia complexes coalesced with one 
another to form tube-like structures referred to as ovigerous cords (Sawyer atal.2002; Figs. 1,2). Pregranulosa cells that form the walls of these cords are thought to be the source of the basal lamina that separate the cords from the surrounding stroma. Thereafter and over a $\sim 40$ day interval, ovigerous cords continue to form within the ovarian cortex. As a result of this segregation, most oogonia and associated pregranulosa cells become isolated from somatic cells in the stromal regions but remain contigious with the OSE (Fig. 1). Here, the mitotically-active oogonia are apparently limited to recruiting pregranulosa cells from the proliferative OSE. It is worth noting that outside the ovigerous cords, residual clusters of germ cell-like cells are evident in the ovarian medulla that do not appear to be associated with somatic cells or bounded by a basal lamina. These cells have been referred to as "lost" germ cells (Sawyer et al., 2002). The interval between Days 55-90 of fetal life is defined by two very significant events. As oogonia contained within the upper regions of the ovigerous cords are recruiting pregranulosa cells from the OSE, those within the lower regions are either entering meiosis or undergoing apoptosis. Indeed, between Days 55-90, over $80 \%$ of the germ cells undergo apoptosis (McNatty et al., 1995). However there is no morphological evidence to suggest that the pregranulosa cells are affected (Sawyer et al., 2002). In fact, it appears that these 'spare' pregranulosa cells are recruited by the surviving oocytes that have completed their maturation through the first stages of meiosis (Sawyer et al., 2002). Thus, the surviving oocytes appear to recruit a sufficient complement of pregranulosa cells (i.e. 16) to form a primordial follicle that becomes isolated from the base of the cord by a complete basal lamina (Lundy et al., 1999). Although the first oogonia enter meiosis on Day 55, the last do not complete this process until $\sim$ Day 120. Nevertheless, by Day 75 , the first primordial follicles begin to emerge from the base of the ovigerous cords at the cortical-medullary interface. And, between Days 75-100 there is a gradual dissolution of the cords as more and more follicles become isolated at the base of each cord (Fig. 2). From Day 75 until complete dissolution of the ovigerous cords, the integrity of the basal lamina is maintained notwithstanding the emergence of primordial follicles each with their own basal lamina. From stereological studies, it is evident in sheep that $>95 \%$ of granulosa cells must have originated from the OSE (Sawyer et al., 2002). A key point with respect to follicular formation is that initial populations of follicles present at the base of the cords after Day 75 of fetal life are amongst the first-formed. Therefore, these follicles are the most likely to contain pregranulosa cells that were recruited from a mesenchymal source during the initial stages of ovigerous cord formation. These are also the first of the follicles to enter the follicular growth phase that is initially observed at $\sim$ Day 90. Moreover, by Day 135 of fetal life (some 10 days before birth), over 20,000 of the early-formed follicles will have entered the growth phase (McNatty et al., 1995). Therefore, as $>25 \%$ of the pool of newly-formed follicles would have entered the growth phase before birth and since $>95 \%$ of the pregranulosa cells originate from the OSE, the evidence would indicate that

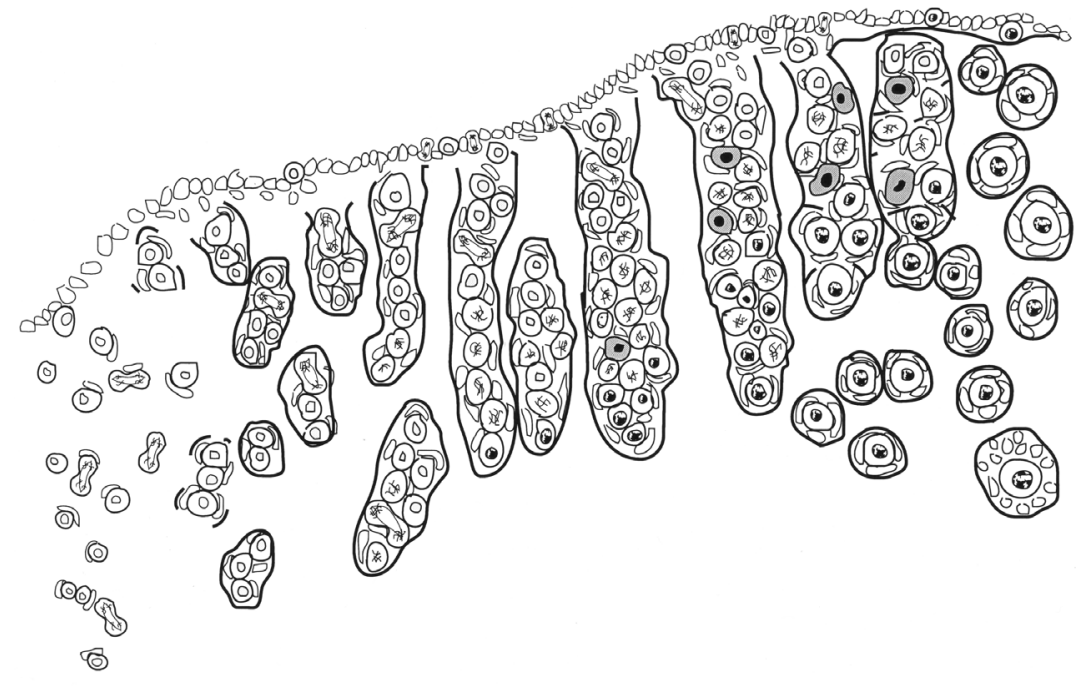

\section{Day 38 Day 45 Day 55 Day 65 Day 75 Day 90 Day 100}

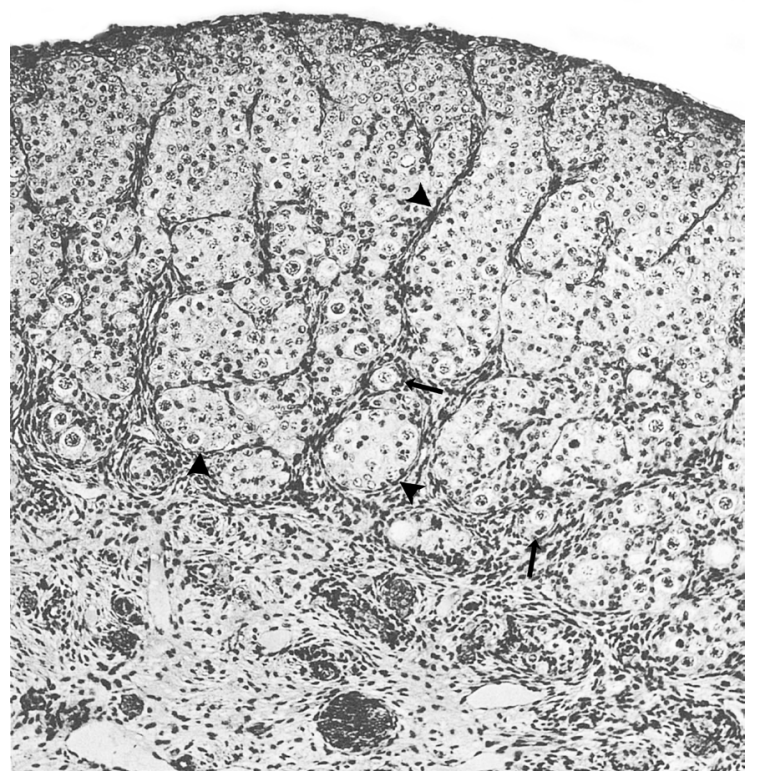

Fig. 2 (Left). Schematic outline of the developing ovary during fetal life in sheep. The $X$ axis refers to gestational age. Non-dividing somatic cells are shown only as irregularly-shaped cell nuclei whereas germ cells are shown as cells with both cytoplasm and nuclei. Nuclei of mitotic epithelial and germ cells are represented by cells with two sets of dividing nuclear material without a distinct nuclear membrane (small cells, epithelial; large cells, germ cells), oogonia are represented by lightly shaded nucleus, meiotic germ cells are represented by cells with chromatin in a string-like configuration in the centre of the cell without a distinct nuclear membrane, apoptotic germ cells are represented as darkly shaded cells with black nuclei and oocytes arrested in the diplotene stage of the first meiotic division are represented with a mottled nucleus. The separated structures at the base of the cords at Days 75-90 are the primordial and primary follicles. This figure was reproduced from Juengel et al., (2002b) with permission from Mol. Cell. Endocrinol.

Fig. 3 (Right). A cross-section of a human fetal ovary at approximately $\mathbf{1 6}$ weeks of gestation. Note the extensive array of cords (arrowheads) that enclose the germ cells and associated pregranulosa cells. Some of the cords appear to be open at the ovarian surface epithelium. Note also the presence of some primordial follicles (arrow) at the base of the cords. This figure was reproduced from van Wagenen and Simpson (1965) with permission from Yale University Press. 
essentially all follicles that first enter the growth phase after birth contain granulosa cells of epithelial origin.

The question arises as to whether granulosa cells in other species also originate from the OSE. Peters (1978) proposed that the contribution of a proliferative OSE to granulosa cell formation in primordial follicles would vary widely between species. In the human, monkey, dog, cat, rabbit and guinea pig there is marked proliferation of the OSE when follicular formation is in progress with no barrier between the germ cells, the OSE and the ovigerous cords. In humans, the sequence of events leading to follicular formation during fetal life closely parallels those in sheep including the formation of "lobules" or ovigerous cords open to the OSE, the prolonged interval of meiosis (>150 days), the massive loss of germ cells $(>70 \%)$ by apoptosis, the first follicles forming at the base of the cords and the very high proportion of follicles entering the growth phase before birth (see Fig. 3; van Wagenen \& Simpson 1965; Baker 1972; Rabinovici \& Jaffe 1990; McNatty et al., 2000). While van Wagenen \& Simpson (1965) describe associations of oogonia with cells of the OSE, it remains uncertain as to what proportion of the granulosa cells are derived from the OSE. This, in part, applies to all species since it is dependent upon the relative proportion of oogonia that attach to mesenchymal cells, the time taken for proliferating oogonia to become segregated from the adjacent stroma and whether the basal lamina extends around the cords within the cortex.

In the mouse, the process of ovarian follicular formation begins during embryonic life but the formation of primordial follicles is not completed until after birth. From embryonic day (ed) 13.5 to 16.5, ovarian cords are established which promote germ cell interaction with somatic cells (Nicholas et al., 2010). In an elegant study using a series of molecular markers, Mork et al., (2012) concluded that pregranulosa cells in this species originated from the OSE. They report that the first 'wave' of follicles that begin to grow in early neonatal life originated from the medullary region. However, the follicles that grow in adult life are those that had formed perinatally from germ cells in the ovarian cortex and which have been encapsulated by epithelial cells during the first days after birth.

Therefore, it can be concluded for the mouse and sheep that most, if not all, granulosa cells in primordial follicles originate

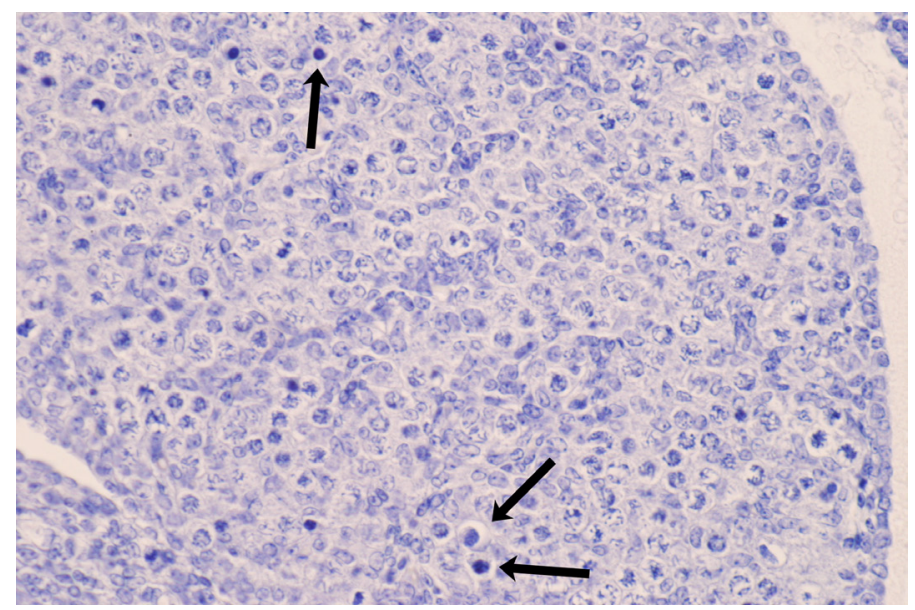

Fig. 4. Representative micrograph of an ovary from a Dazl-KO mouse aged at embryonic day 18. Note the high number of degenerating oogonia (arrows) throughout the section. from the OSE. Recently, Mora et al., (2012) reported that the granulosa cells in primordial follicles of the mouse do not display all the characteristics of a classical epithelial cell phenotype due to a lack of tight junctions and an absence in expression of many common epithelial markers such as E-cadherin and cytokeratin 8. However, this is perhaps not unexpected as the epithelial cells being recruited by oogonia for follicular formation are from a proliferating and dispersed population (Sawyer et al., 2002). Oogonia then attach to these dispersed epithelial cells via desmosome or adhesion junctions. Thus, as soon as the epithelial cells leave the surface of the ovary, the oogonia/oocyte and not the OSE becomes the primary influence in determining their fate and phenotype.

\section{The fate of granulosa cells in Dazl-KO mice}

The DAZL protein is an RNA-binding protein present in the cytoplasm of both oogonia and oocytes (Brook et al., 2009). The presence of DAZL is critical for oogenesis and the formation of primordial follicles and thus fertility (Ruggiu et al., 1997; McNeilly et al., 2000, 2010). By embryonic day (ed) 18 in homozygous Dazl-KO mice, some oogonia were degenerating although many of the germ cells appeared morphologically normal (Fig. 4). At birth, most of the oogonia/oocytes present were degenerating whilst the pregranulosa cells remained viable (Fig. 5B). In contrast, in the wild-type (WT) animals at birth, oogonia/oocytes were most commonly located in 'nests' and were either in contact with pregranulosa cells or in the process of primordial follicular assembly (Fig. 5A). By Day 7 of postnatal life in WT mice, primordial follicle formation was complete (Fig. 5C) and some follicles had initiated growth, some even reaching the preantral stages (data not shown). In the homozygous KO mice, some residual mostly degenerating oogonia/oocytes were still located within 'nests' and associated with pregranulosa cells, but there was no evidence of primordial follicle formation (Fig. 5D). By Day 21, there was no evidence of germ cells within the ovaries, but sex-cords and intraovarian tubules/ducts were frequently observed (Fig. 5E-H). Regions of OSE were actively proliferating and luteal-like cells with a large 'foamy' cytoplasm either localised individually, or in clusters, were often present (Fig. 5G). Some but not all, of these luteal-like cells expressed $3 \beta \mathrm{HSD}$ but there was no evidence for $\mathrm{AMH}$ or inhibin expression in these cells or any other ovarian cell types. Additionally, isolated cells or clusters of cells within the ovarian stroma were immuno-positive for cytochrome P450 aromatase and 17 $\alpha$ hydroxylase. Surprisingly, despite the increasingly cellular disorganisation within the ovaries, an absence of follicles and very low plasma levels of inhibin $\alpha / \beta$, the plasma concentrations of oestradiol and progesterone in $\mathrm{KO}$ mice at 8-12 weeks of age were similar to those in WT mice. Moreover, plasma concentrations of FSH and LH were significantly higher in the Dazl-KO compared to that in WT mice (McNeilly et al., 2000). By 9 months of age in some Dazl-KO mice, either one or both ovaries were abnormally large in size and on some occasions one of the ovaries had a streaklike appearance. A common feature of the enlarged ovaries was the presence of an extensive array of intraovarian cords/ducts and an irregularly contoured OSE with deep invaginations, both of which stained positively for pancytokeratin (Fig. $5 \mathrm{H}$ ). Another characteristic of the KO ovaries, irrespective of size, were clusters/ islands of luteal-like cells interspersed between the intraovarian tubules/ducts, which appeared to become increasingly prominent 
with age. Critically, as assessed by PCNA immunocytochemistry, the extent of ovarian cell proliferation in Dazl-KO mice remained low despite some ovaries exhibiting surface areas absent of OSE, and an apparant integration of the ovarian interstitium with extraovarian fat cells. Nonetheless, there remained no evidence for unusually high mitotic activity, multinucleated cells or metastases in ovaries of $\mathrm{KO}$ mice.

It is concluded that in mice devoid of DAZL protein, germ cells are unable to complete meiosis or to form follicles. Although the number of somatic cells incorporated in the cords containing oocytes remains to be determined, it seems that only a limited number of epithelial cells would be recruited by the oogonia/ oocytes given the high level of germ cell degeneration before and around the time of birth. Importantly, in this animal model, no discrete follicular-enclosed structures containing granulosa cells are formed. Since all oogonia/oocytes degenerate before follicles are formed, the surviving somatic cells, that are presumed to be epithelial in origin, are retained within cord-like structures. Although the extent of mitotic activity of these cells remains low, these cord-like structures together with invaginations of the OSE and clusters of luteal-like (steroidogenic) cells become increasingly prominent with age. The increasing propensity of cellular luteinisation is most likely a consequence of elevated gonadotrophin secretion in these KO mice. In conclusion, the abnormal ovarian structures that arise in the Dazl-KO mice are benign as there is no evidence of $\mathrm{OC}$ in this phenotype.

\section{The fate of granulosa cells in Fancd2-KO mice}

Fanconi anaemia (FA) is a rare hereditary disease characterised by bone marrow failure, congenital defects and the development of cancers (Bagby \& Alter 2006). The fifteen known FA proteins are clearly involved in DNArepair but there is increasing evidence that at least some of them have additional functions, including the support of stem cell pluripotency (Dao et al., 2012). FANCD2 is clearly an important component of repair complex formation. Damaged induced nuclear foci contain both BRCA2 and mono-ubiquitinylated FANCD2. The ubiquitinylation of FANCD2 is absolutely required for the formation of foci and its ubiquitinylation depends entirely upon the formation of an intact multimeric FA complex consisting of at least 8 FA proteins (Wang et al., 2004; Bagby \& Alter 2006; Thompson \& Hinz 2009). In the developing human ovary, FANCD2 protein is immunolocalised in both proliferating granulosa cells in growing follicles and oocytes before birth (Holzel et al., 2003). In the testes, FANCD2 protein was expressed in spermatids, spermatozoa and Sertoli cells, but not in spermatocytes (Holzel et al., 2003). These findings suggest that FANCD2 protein has a role during DNA replication and meiotic maturation. Recently, a Fancd2-KO mouse has been created (Houghtaling et al., 2003) and these mice display a high prevalence of ovarian epithelial tumours. The location of the FANCD2 gene is linked to the site of familial OC in the human genome (Houghtaling et al., 2003) and FANCD2 plays an important role in human ovarian tumorigenesis, as FANCD2 protein is low in the OSE of high-risk women (Pejovic et al., 2006) and over-expressed in patients with poor prognosis (Wysham et al., 2012). The Fancd2-KO mice have previously been reported to contain ovarian follicles although the numbers observed in the follicular growth phase were small. Herein, we describe that the Fancd2-KO mice at 2-3 months of age contain primordial follicles but thereafter no follicles were observed with all homozygous mutants containing ovarian tumours with multiple phenotypes including epithelial carcinomas. The results of these
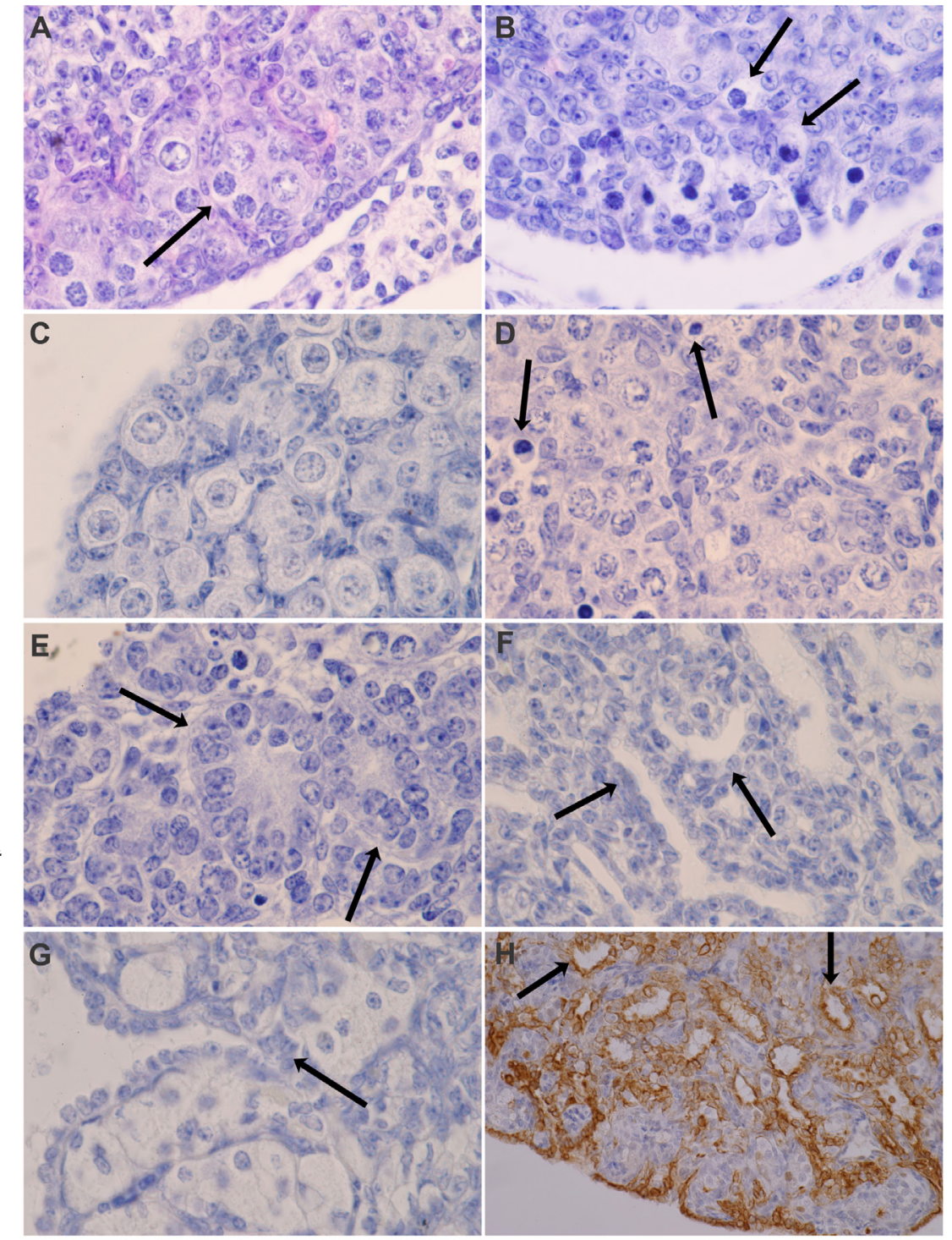

Fig. 5. Representative micrographs of ovary sections from Dazl-WT $(A, C)$ and -KO (B, $D-H)$ mice at 0 days $(A, B), 7$ days $(C, D), 21$ days $(E), 3$ months $(H)$ and 9 months $(F, G)$ of age after birth. Note the healthy appearance of oogonia/oocytes clustered in ovigerous cords (arrow) (A) or closely-associated with pregranulosa cells (C) in 0-7 day old WT mice compared to degenerating oogonia/oocytes (arrows) and numerous haphazard areas of granulosa cells in similar-aged KO mice (B,D). Common abnormal ovarian phenotypes in Dazl-KO mice include the formation of numerous sex cords (arrows) (E), tubules (arrows) $(\mathbf{F}, \mathbf{H})$ which label positively for pancytokeratin $(\mathbf{H})$, invagination of ovarian surface epithelium (arrow) (G) and areas of luteinised cells of spongy appearance (G). 
studies are summarised in Table 1 with examples of the ovarian morphologies shown in Fig. 6. Despite the cellular abnormalities in the ovaries of Fancd2-KO mice, no unusual pathologies were observed in those immediately-associated fallopian tubes that were collected.

From the four $<5$ month old Fancd2-KO mice investigated, only the ovaries from the two youngest mice ( $<3$ months old)
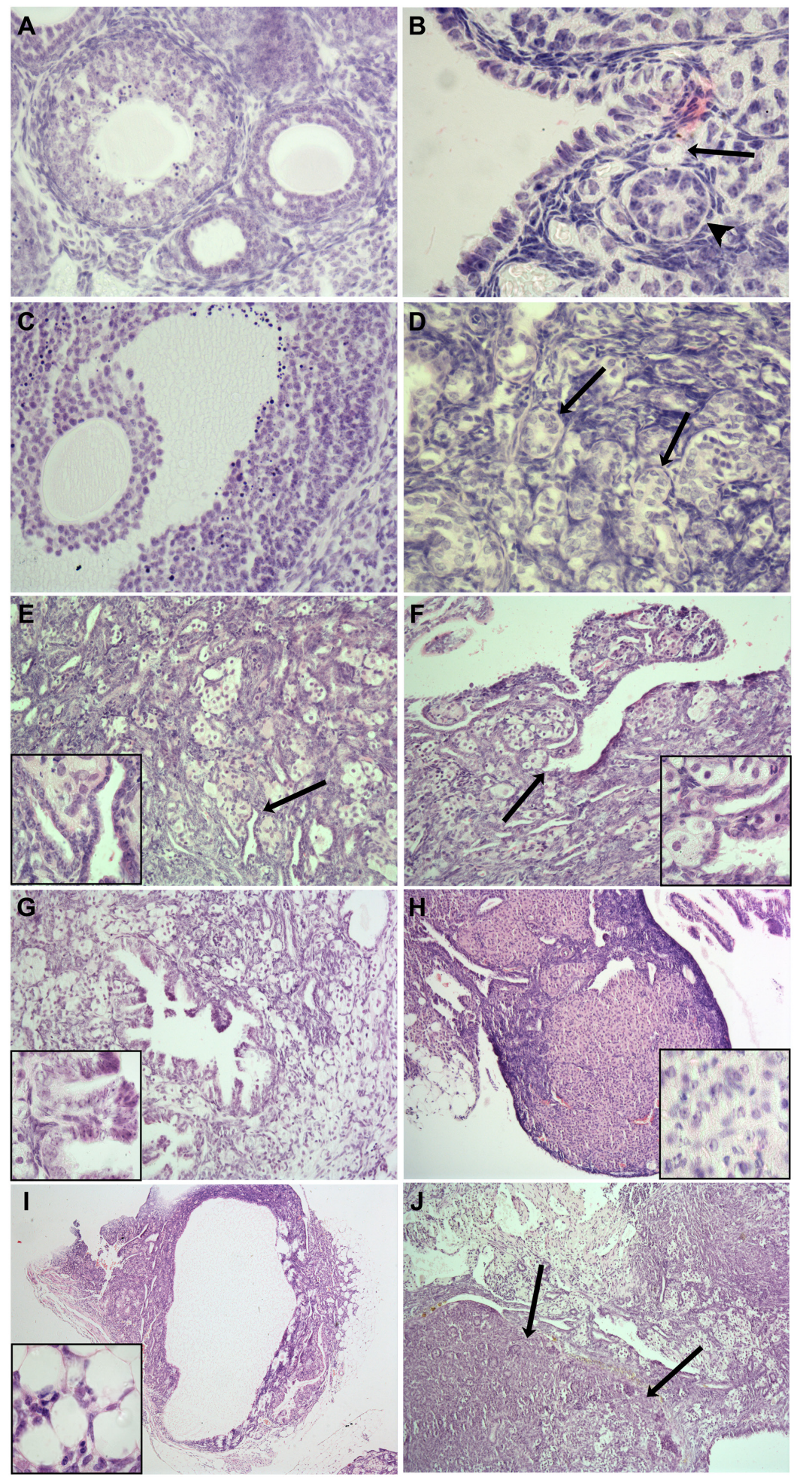

contained follicles at the primordial, preantral and antral stages of development confirming the results from a previous report (Fig. 6B, 6C; Houghtaling et al., 2003). All of the large preantral and antral follicles present were undergoing atresia as assessed by the large numbers of pycnotic granulosa cells (Fig. 6C). In contrast, in the limited numbers of primordial follicles observed, there was evidence of oocyte but not granulosa cell degeneration (Fig. 6B). After 3 months of age, no ovarian follicles nor normal corporalutea were observed. An early pathological event in the ovaries of all four Fancd2-KO mice that were $<5$ months of age was the presence of sex cords (Fig. 6D), intraovarian epithelial ducts (Fig. 6E) and some invagination of the OSE (Fig. 6F). In ovaries of Fancd2-KO mice from 5-<9 months of age, the ovarian area containing sex cords had increased, together with an increasing presence of discreet areas of tubulostromal adenomas (Fig. 6E), luteomas (Fig. 6H) and intraovarian epithelial cysts (Fig. 6I). Some of these epithelial cysts had a papillary or a mucinous phenotype (Fig. 6G). Large areas of OSE were irregular and invagination was common. By 9 months of age, ovaries from Fancd2-KO mice contained integrated tumours of multiple phenotypes including adenocarcinomas whereby highly mitotic cells were invading extraovarian fat cells (Fig. 6 I,J).

The widespread presence of ovarian sex cords and epithelial ducts in the Fancd2-KO mice is reminiscent of early changes in the Dazl-KO mice following loss of oogonia/oocytes but not the pregranulosa cells. In the youngest Fancd2-KO whereby follicles were observed, the granulosa cells of growing, but not primordial, follicles were undergoing apoptosis. This concurs with the localisation studies in developing human ovaries where the FANCD2 protein is localised to granulosa cells of growing follicles and oocytes (Holzel et al., 2003). Therefore, one interpretation of these early pathological events is that tumorigenesis in these aforementioned mice models is due to the uncontrolled growth of granulosa cells from pre-existing primordial follicles that are devoid of their germ cell regulator.

However, the Fancd2-KO is a very complex animal model with the onset of ovarian pathological changes evident early in neonatal life. This complexity arises because, in the absence of FANCD2 protein, survival

Fig. 6. Representative micrographs of ovary sections from Fancd2-WT (A) and -KO (B-J) mice at 2.5 (A-C), 5-9 (D-I) and $12(\mathrm{~J})$ months of age after birth. Note the appearance of primordial (arrow) (B), preantral (arrowhead) (B) and antral (C) follicles in ovaries of Fancd2-KO mice, similar to that in WT mice (A). Common abnormal ovarian phenotypes in Fancd2-KO mice include: the formation of numerous sex cords (arrows) (D); tubules (high magnification inset; arrow) (E); invagination of ovarian surface epithelium (high magnification inset, arrow) (F); cystic papillary hyperplasias (high magnification inset (G); luteomas containing large areas of cells of spongy appearance (high magnification inset $\mathbf{( H ) ; ~ c y s t a d e n o c a r i n o m a ~ w h e r e b y ~}$ mitotically-active cells are invading extraovarian fat cells (high magnification inset (I); and large areas containing numerous tumour phenotypes of epithelial origin, including adenocarcinomas (arrows) (J). 
TABLE 1

\section{OVARIAN CHARACTERISTICS IN HOMOZYGOUS (HOM) AND HETEROZYGOUS (HET) FANCD2-MUTANTS AND WILD-TYPE (WT) MICE}

\begin{tabular}{|c|c|c|c|c|}
\hline $\begin{array}{l}\text { Classification } \\
\text { (Number of mice) }\end{array}$ & $\begin{array}{l}\text { Age range, } \\
\text { months }\end{array}$ & Follicles and corpora lutea & Cysts/abnormal structures & Tumours ${ }^{1}$ \\
\hline Wt (2) & $2-<5$ & Yes, 2/2 & None & None \\
\hline Het (3) & $2-<5$ & $3 / 3$, follicles; $2 / 3$ with $C L$ & None & None \\
\hline Hom (4) & $2-<5$ & $\begin{array}{l}2 / 4 \text { at } 2-3 \text { months with follicles, } 2 / 4 \text { at } 4 \\
\text { months no follicles and } 4 / 4 \text { no } C L\end{array}$ & $4 / 4$ & $\begin{array}{l}4 / 4 \text { with sex cords and/or intraovarian epithelial cell cysts/ducts. Tubulo- } \\
\text { stromal hyperplasias or adenomas. No malignancies }\end{array}$ \\
\hline Wt (6) & $>5-12$ & Yes, $6 / 6$ & None & None \\
\hline Het (8) & $>5-12$ & $\begin{array}{l}7 / 8 \text { follicles } \& C L \\
1 / 8 \text { no follicles or } C L\end{array}$ & $\begin{array}{l}4 / 8 \text { with } \geq 1 \text { intraovarian epithelial cyst } \\
\text { (one with a papillary cyst }\end{array}$ & $\begin{array}{l}1 / 8 \text { no follicles but with a cyst adenoma, sex cords, a papillary cyst and a } \\
\text { tubulostromal adenoma with metastases }\end{array}$ \\
\hline Hom (7) & $>5-12$ & $0 / 7$ & $\begin{array}{l}7 / 7 \text { with intraovarian epithelial cysts, some } \\
\text { with papillary hyperplasia }\end{array}$ & $\begin{array}{l}7 / 7 \text { with mixed sex cords/luteomas. } 2 / 7 \text { animals with evidence of } \\
\text { malignancy with cell masses migrating across the extra-ovarian fat pad. }\end{array}$ \\
\hline Wt (4) & $>12$ & Yes, $4 / 4$ & None & None \\
\hline Het (11) & $>12$ & 9 & $\begin{array}{l}7 / 11 \text { with } \geq 1 \text { intraovarian cysts some with } \\
\text { papillary hyperplasias }\end{array}$ & $\begin{array}{l}1 / 11 \text { with sex cords, tubulo-stromal adenoma and adenocarcinoma and } \\
\text { growing follicles }\end{array}$ \\
\hline Hom (8) & $>12$ & 0/8 with follicles or $\mathrm{CL}$ & $\begin{array}{l}8 / 8 \text { with follicles and } C L \text { with abnormal } \\
\text { cysts }\end{array}$ & $\begin{array}{l}\text { 8/8 Multiple phenotypes: sex cord tumours, adenocarcinomas, tubulo- } \\
\text { stromal hyperplasias and some with papillary cysts. }\end{array}$ \\
\hline
\end{tabular}

'Tumour classifications based on those reported by Mohr (2001)

of oocytes is seriously impaired and the ongoing risk to DNA damage in the follicular cells and other ovarian cell-types is increased. While further studies are required, it is evident that oocytes in all primordial follicles die within the first month of neonatal life, and that extensive and rapid remodelling of the ovary occurs with an increasing abundance of sex cords and intraovarian epithelial-like tubules that are sometimes, but not always, continuous with the OSE. Thereafter, tumours with multiple phenotypes develop with some fulfilling the criteria of malignant carcinomas. The question arises as to whether granulosa cells contribute to these phenotypes? This will require further study. Our interpretation is that the epithelial-derived granulosa cells from primordial follicles are a significant contributor to the sex cords and intraovarian derived tubules following oocyte loss. We suggest that these cells together with those derived from the OSE contribute to the origins of both the benign and malignant carcinomas observed in this model.

\section{The fate of granulosa cells in BMP15 deficient sheep}

Female sheep with homozygous inactivating mutations in the pro- or mature-regions of the BMP15 gene are infertile (Galloway et al., 2000). Normal follicular development is blocked at the primary follicle stage and the ovaries present with a "streak" appearance (Braw-Tal et al., 1993). However, the numbers of follicles that form during fetal life and the proportions of follicles that initiate growth in either fetal or neonatal life were not different between the homozygous-mutant and wild-type ewes (Braw-Tal et al., 1993; Smith et al., 1997; McNatty et al., 2001). Following the initiation of follicular growth in the BMP15 deficient animals, oocytes enlarge from $\sim 25$ to $\sim 80 \mu \mathrm{m}$ in diameter, but without a concomitant increase in the numbers of granulosa cells. In wild-type ewes, there is a 9-15 fold increase in the number of granulosa cells as oocytes enlarge to $80 \mu \mathrm{m}$ compared to $a<3$-fold increase in homozygous-mutant ewes which was accompanied by a significant cellular disorganisation but no evidence of apoptosis (Braw-Tal et al., 1993; Smith et al., 1997). A common feature in all homozygous BMP15 mutant ewes was that the enlarging oocytes all degenerate leaving remnants of zona pellucida and oocyte-devoid follicular 'nodules' (Fig. 7).

As the numbers of these nodules increased over time, they often coalesced to form large solid or semi-solid (fluid-filled) structures that in some cases secreted inhibin (Braw-Tal et al., 1993; see also Fig. 8). As these large abnormal structures (tumours) developed, circulating plasma levels of FSH declined from those found typically in ovariectomized ewes to levels observed in ovary-intact animals. Subsequently, in the absence of elevated FSH, these tumours regressed but then were followed by the asynchronous growth of more tumour-like structures so that this cycle of growth and regression was self-sustaining (McLeod et al., 1995). This implies that the tumours, as they grow, have the capacity to ex-
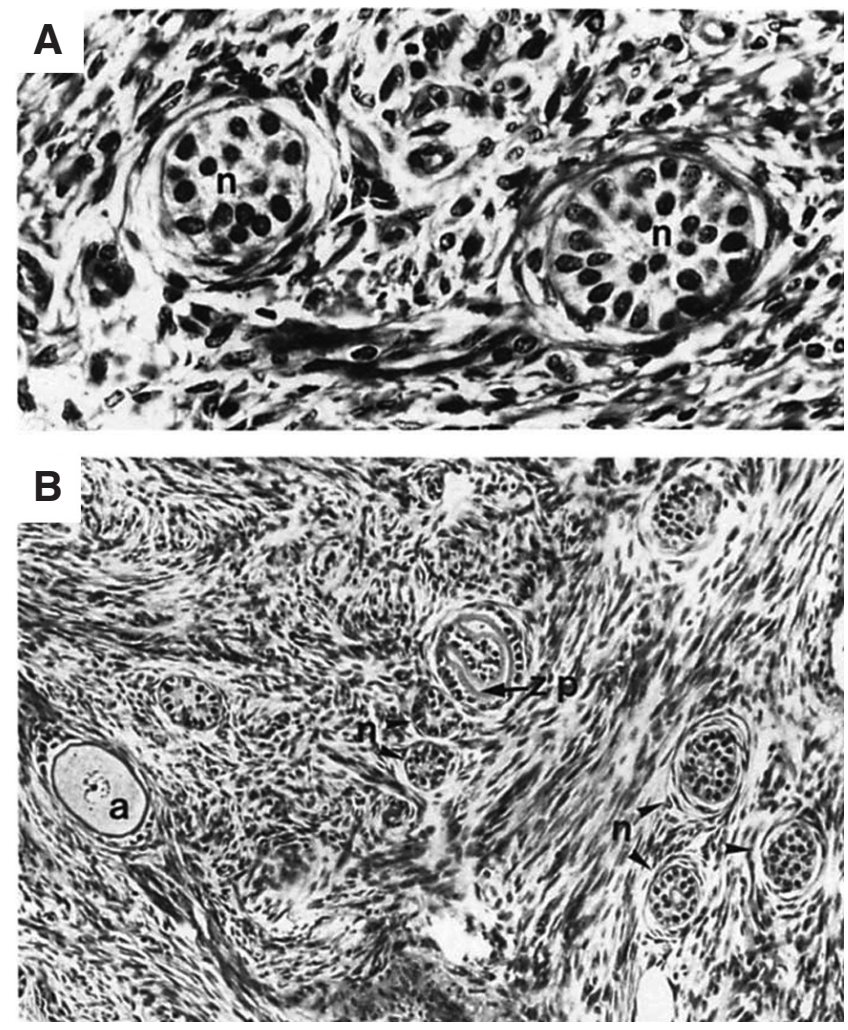

Fig. 7. Sections through ovaries from homozygous BMP15 mutant sheep showing follicular structures devoid of oocytes and zona pellucida (A). These are referred to as nodules (n). (B) Abnormal follicle (a), nodules (n) and a nodule with a remnant of zona pellucida (p). This figure was reproduced from Braw-Tal et al., (1993) with permission from Biol. Reprod. 
press biologically-active inhibin dimer which would suppress $\mathrm{FSH}$. A common feature of these nodules and tumours was that they expressed a range of genes (i.e. FSHR, follistatin, $\alpha$ - inhibin, $\beta A$ and $\beta B$-inhibin/activin subunit, Juengel et al., 2000; Fig. 8) that are normally only expressed in granulosa cells of type 3 (preantral) follicles and not in any other ovarian cell type (McNatty et al., 1999). Additionally, other abnormal ovarian phenotypes of granulosa cell origin as assessed by their gene expression profiles or secretory products were also evident (Braw-Tal et al., 1993; Juengel et al., 2000). These included large, irregular-shaped luteal-like structures and very large (i.e. 20-35 mm diameter) clear fluid- or blood-filled cysts that secreted variable amounts of inhibin, oestradiol, and/ or progesterone.

In some homozygous mutants, the presence of extensive areas of extracellular matrix have been reported together with the presence of invasive fibroblast-like tissue and cuboidal cells rich in brown pigment either in cortical regions or the medulla (BrawTal et al., 1993). Subsequent studies to trace the origins of these abnormalities have not been undertaken. While tumour-like tissues are a common occurrence in homozygous BMP15 mutant sheep, none have ever manifested as metastasizing tumours or contributed to a shortened life-expectancy of these animals relative to the wild-types. Thus for this animal model, it can be concluded that when oocytes die prematurely after follicular growth is initiated, these differentiated granulosa cells go on to form benign solid, semi-solid or cystic tumour-like structures that are stimulated to

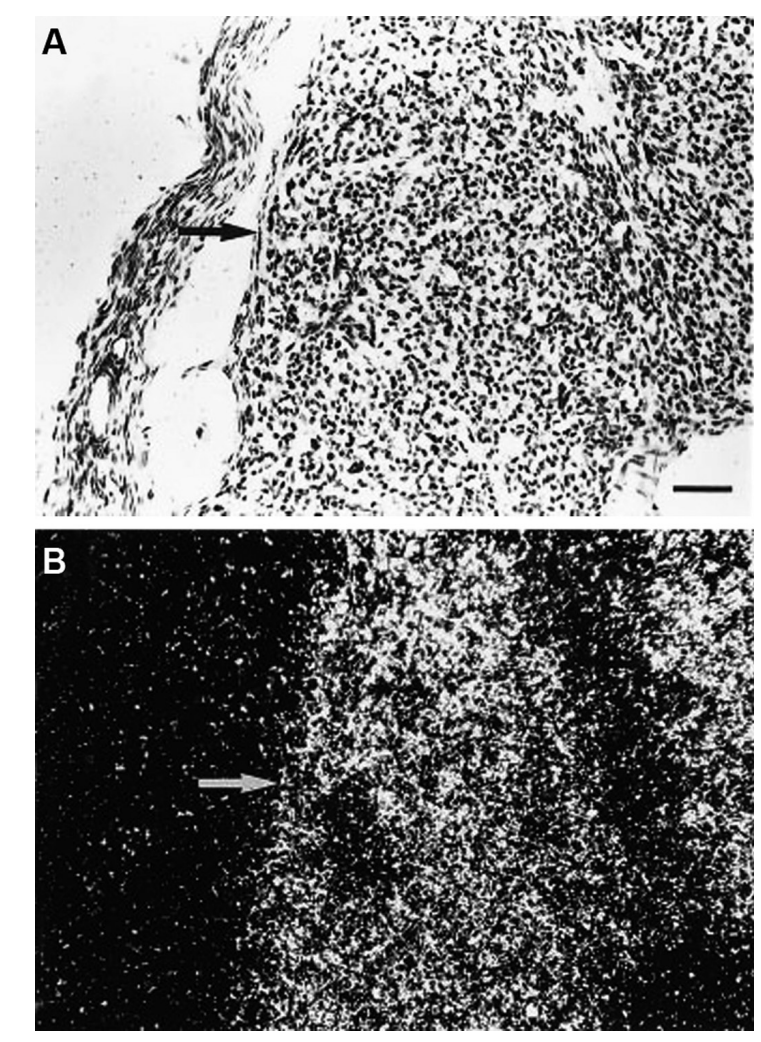

Fig. 8. Corresponding bright-field (A) and dark-field (B) views of ovarian tissue from a homozygous BMP15-mutant sheep of a large solid tissue of granulosa cell origin expressing the $\beta A$-activin/inhibin subunit. This figure was reproduced from Juengel et al. (2002) with permission from Biol. Reprod. grow through the actions of FSH (Kumar et al., 1999). Thereafter, the regression of these tumours is highly correlated to their ability to secrete inhibin and suppress circulating levels of $\mathrm{FSH}$. This interpretation is consistent with the role of inhibin as a tumoursuppressor hormone (Matzuk et al., 1992) and the reason why these tumours are benign.

Another useful model worthy of further analysis is the Thoka GDF9-KO sheep model (Nicol et al., 2009). In these animals, oocytes also enlarge to $80 \mu \mathrm{m}$ in "growing" follicles but unlike the BMP15-KO sheep, no more than two abnormal layers of granulosa cells are observed. In this animal model, the oocytes but not granulosa cells die, leaving oocyte-deficient nodules. However, no abnormal tumour-like structures were observed and plasma inhibin levels were low. This may support the notion that the surviving granulosa cells had transformed from an epithelial phenotype but had not acquired responsiveness to $\mathrm{FSH}$ to develop the tumour phenotypes that are observed in the BMP15-KO sheep.

\section{Discussion and Conclusions}

The three animal models chosen for this review represent examples of sequeale whereby germ cells or oocytes die at specific stages of follicular formation or growth leaving behind clusters of residual, but healthy somatic cells. These somatic cells, which are referred to as either pregranulosa or granulosa cells, are derived from the OSE. Since the origins and precipitating causes of OC remains to be determined, it is reasonable to speculate that granulosa cells contribute to carcinomas of epithelial origins, as well as to the more rare prevalence of granulosa cell carcinomas which represent only around $5 \%$ of human OC (Robertson et al., 2007). It is evident from the BMP15-mutant sheep model that once the granulosa cells develop a partially-differentiated phenotype, including receptivity to $\mathrm{FSH}$ and a capacity to secrete inhibin, multiple tumour phenotypes can arise but appear to be benign. In the Dazl-KO mouse model, pregranulosa cells become associated with oogonia in cords during the interval preceding follicle formation, but follicles fail to form as the oogonia/oocytes die. In this model, intraovarian ducts and clusters of luteal-like cells form, but are mostly benign. The Dazl-KO mice ovaries do not produce inhibin, but stromal/interstitial cells become steroidogenically active. While it seems likely that the intraovarian epithelial-like cords are of granulosa and/or OSE origin, this remains to be confirmed. The Fancd2-KO model is unique as almost all animals develop adenomas, and with time many develop adenocarcinomas and other aggressive/invasive tumours. Acommon feature in this model is the rapid appearance of extensive sex cords and intraovarian epithelial-like tubules that is coincident with the loss of oocytes during the first months of life. Therefore it is possible that the abnormal ovarian pathologies that are specific to each of the three models addressed in this review are due to the timing of oocyte loss in relation to follicular assembly and formation.

At present, there are only a limited number of models in which to examine the aetiology of OC. All OC cell lines are derived from existing tumours. Moreover, $\mathrm{OC}$ is often only diagnosed in the late stages of tumour progression. The different animal models reported herein provide a unique opportunity to determine the progressive changes in gene expression profiles and hence molecular mechanisms that change over time as tumours develop following germ cell loss. 
We conclude that premature loss of germ cells leads to ovarian tumour formation with multiple phenotypes. The molecular mechanisms involved in this process are not yet defined nor are the potential roles of the granulosa cells and the cells of the stroma and sex cords. Nonetheless, the intriguing association of these cell types with the neoplastic process suggests that further study will be worthwhile.

\section{Acknowledgements}

The authors wish to acknowledge the advice and assistance of Dr D.N. Rao Veeramachineni, Colorado State University on aspects of this study. We also wish to thank Ms Norma Hudson, Victoria University of Wellington for the serial sectioning of many ovaries investigated in this study. Funding support was provided by the Health Research Council of New Zealand to JLP (hrc10/218).

\section{References}

AUERSPERG N. (2011). The origin of ovarian carcinomas: a unifying hypothesis. Int $J$ Gynecol Pathol 30: 12-31.

BAGBY G.C. and ALTER B.P. (2006). Fanconi anemia. Semin Hematol 43: 147-156.

BAKER T.G. (1972). Oogenesis and ovarian development In: Reproductive Biology (Eds. H. Balin and S. Glasser). Excerpta Medica, Amsterdam, pp 398-437.

BOWEN N.J., WALKER L.D., MATYUNINA L.V., LOGANI S., TOTTEN K.A., BENIGNO B.B. and MCDONALD J.F. (2009). Gene expression profiling supports the hypothesis that human ovarian cancer epithelia are multipotent and capable of serving as ovarian cancer initiating cells. BMC Med Genomics 2: 71.

BRAW-TAL R., MCNATTY K.P., SMITH P., HEATH D.A., HUDSON N.L., PHILLIPS D.J., MCLEOD B.J. and DAVIS GH (1993). Ovaries of ewes homozygous for the $\mathrm{X}$-linked Inverdale gene (Fec $\mathrm{X}^{\prime}$ ) are devoid of secondary and tertiary follicles but contain many abnormal structures. Biol Reprod 49: 895-907.

BROOK M., SMITH J.W.S. and GRAY N.K. (2009). The DAZL and PABP families: RNA-binding proteins with interrelated roles in translational control in oocytes. Reproduction 137: 595-617.

DAO K.H., ROTELLI M.D., PETERSEN C.L., KAECH S., NELSON W.D., YATES J.E., NEWELL A.H., OLSON S.B., DRUKER B.J., and BAGBY G.C. (2012). FANCL ubiquitinates beta-catenin and enhances its nuclear function. Blood DOI: 10.1182/ blood-2011-11-388355

DONG J.L., ALBERTINI D.F., NISHIMORI K., KUMART.R., LU N. and MATZUK M.M. (1996). Growth differentiation factor-9 is required during early folliculogenesis. Nature 383: 531-535.

EPPIG J.J. (2001). Oocyte control of ovarian follicular development and function in mammals. Reproduction 122: 829-838.

FULLER P., CHU S., FIKRET S. and BURGER H. (2002). Molecular pathogenesis of granulosa cell tumours. Mol Cell Endocrinol 191: 89-96.

GALLOWAY S.M., MCNATTY K.P., CAMBRIDGE L.M., LAITINEN M.P.E., JUENGEL J.L., JOKIRANTA S., MCLAREN R.J., LUIRO K., DODDS K.G., MONTGOMERY G.W., BEATTIEA.E., DAVIS G.H. and RITVOS O. (2000). Mutations in an oocytederived growth factor gene (BMP15) cause increased ovulation rate and infertility in a dosage sensitive manner. Nat Genet 25: 279-283.

GILCHRIST R.B., RITTER L.J. and ARMSTRONG D.T. (2001). Mouse oocyte mitogenic activity is developmentally coordinated throughout folliculogenesis and meiotic maturation. Dev Biol 240: 289-298.

GUTHRIE M. (1958). Tumorigenesis in ovaries of mice after X irradiation. Cancer 11: 1226-1235.

HANRAHAN J.P., GREGAN S.M., MULSANT P., MULLEN M., DAVIS G.H., POWELL R. and GALLOWAYS.M. (2004). Mutations in the genes for oocyte-derived growth factors GDF9 and BMP15 are associated with both increased ovulation rate and sterility in Cambridge and Belclare sheep (Ovis aries). Biol Reprod 70: 900-909.

HOLZEL M., VAN DIEST P.J., BIER P., WALLISCH M., HOATLIN M.E., JOENJE H. and DE WINTER J.P. (2003). FANCD2 protein is expressed in proliferating cells of human tissues that are cancer-prone in Fanconi anaemia. J Pathol 201: 198-203.

HOUGHTALING S., TIMMERS, C., NOLL M., FINEGOLD M.J., JONES S.N., MEYN M.S. and GROMPE M. (2003). Epithelial cancer in Fanconi anemia complementa- tion group D2 (Fancd2) knockout mice. Genes Dev 17: 2021-2035.

HOWELL J.S., MARCHANT J. and ORR J.W. (1954). Induction of ovarian tumours in mice with 9:10-dimethyl-1,2-benzanthracene. Br J Cancer 8: 635-646.

JUENGELJ.L., QUIRKE L.D., TISDALLD.J., SMITH P., HUDSON N.L. and MCNATTY K.P. (2000). Gene expression in abnormal ovarian structures of ewes homozygous for the Inverdale prolificacy gene. Biol Reprod 62: 1467-1478.

JUENGEL J.L., HUDSON N.L., HEATH D.A., SMITH P., READER K.L., LAWRENCE S.B., O'CONNELL A.R., LAITINEN M.P.E., CRANFIELD M., GROOME N.P. RITVOS, O. and MCNATTY K.P. (2002a). Growth differentiation factor 9 and bone morphogenetic protein 15 are essential for ovarian follicular development in sheep. Biol Reprod 67: 1777-1789.

JUENGEL J.L., SAWYER H.R., SMITH P.R., QUIRKE L.D., HEATH D.A., LUN S. WAKEFIELD S.T.J. and MCNATTY K.P. (2002b). Origins of follicular cells and ontogeny of steroidogenesis in ovine fetal ovaries. Mol Cell Endocrinol 191: 1-10.

KIM J., COFFEY D.M., CREIGHTON C.J., YU Z., HAWKINS S.M. and MATZUK M.M. (2012). High grade serous ovarian cancer arises from fallopian tube in a mouse model. Proc Natl Acad Sci USA 109: 3921-3926.

KRARUP T. (1970). Effect of 9,10-dimethyl-1,2-benzanthracene on the mouse ovary Ovarian tumorigenesis. Br J Cancer 24: 168-186.

KURMANR.J. and SHIHI.-M. (2010). The origin and pathogenesis of epithelial ovarian cancer: a proposed unifying theory. Am J Surg Pathol 34: 433-443.

KUMAR T.R., PALAPATTU G., WANG P., WOODRUFF T.K., BOIME I., BYRNE M.C. and MATZUK M.M. (1999). Transgenic models to study gonadotropin function: the role of follicle- stimulating hormone in gonadal growth and tumorigenesis. Mol Endocrinol 13: 851-865.

LUNDY T., SMITH P., O'CONNELL A., HUDSON N.L. and MCNATTY K.P. (1999). Populations of granulosa cells in small follicles of the sheep ovary. $J$ Reprod Fertil 115: 251-262.

MATZUK M.M., FINEGOLD M.J., SU J.G., HSUEH A.J. and BRADLEY A. (1992). Alpha-inhibin is a tumour-suppressor gene with gonadal specificity in mice. Nature 360: 313-319.

MOHR U. (Ed.) (2001). International classification of rodent tumors: The mouse. Springer-Verlag, Berlin.

MCLEOD B.J., KYLE S.E., RAMSAY M.R. and MANLEY T.R. (1995). Hormone secretion patterns associated with increased ovulation rates or with ovarian dysfunction in Inverdale (FecX) ewes. Proc NZ Soc Anim Prod 55: 304-306.

MCNATTY K.P., JUENGEL J.L., WILSON T., GALLOWAY S.M. and DAVIS G.H. (2001). Genetic mutations influencing ovulation rate in sheep. Reprod Fertil Dev 13: $549-555$

MCNATTY K.P., HEATH D.A., LUNDY T., FIDLER A.E., QUIRKE L., O'CONNELL A., SMITH P., GROOME N. and TISDALL D.J. (1999). Control of early follicular development. J Reprod Fertil Supp/ 54: 3-16.

MCNATTY K.P., QUIRKE L.D., FIDLER A., SMITH P., HEATH D.A. and TISDALL D. (2000). Ovarian development: fetus to puberty. In Hormones and Women's Health. (Ed. L.A. Salamonsen). Harwood Academic Publishers, pp 9-22.

MCNATTY K.P., SMITH P., HUDSON N.L., HEATH D.A., TISDALL D.J., O W.-S. and BRAW-TAL R. (1995). Development of the sheep ovary during fetal and early neonatal life and the effect of fecundity genes. J Reprod Fertil Supp/ 49:113-121.

MCNEILLY J.R., SAUNDERS P.T.K., TAGGART M., CRANFIELD M., COOKE H.J. and MCNEILLY A.S. (2000). Loss of oocytes in Dazl knockout mice results in maintained ovarian steroidogenic function but altered gonadotrophin secretion in adult animals. Endocrinology 141: 4284-4294.

MCNEILLY J.R., MCNATTY K.P. and MCNEILLY A.S. (2010). The consequences of germ cell loss on ovarian development in neonatal Dazl knockout mice. Conf Proc Soc Reprod Fertil, Abstract 011

MORAJ.M., FENWICKM.A., CASTLE L., BAITHUN M., MOBBERLYM., CARZANIQA R., FRANKS S. and HARDYK. (2012). Characterization and significance of adhesion and junction-related proteins in mouse ovarian follicles. Biol Reprod 153: 1-14.

MORK L., MAATOUL D.M., MCMAHON J.A., GUO J.J., MCMAHON A.P. and CAPEL B. (2012). Temporal differences in granulosa cell specification in the ovary reflect distinct follicle fates in mice. Biol Reprod 86: 1-9.

MULLANY, L.K., FAN H.-Y., LIU Z., WHITE L.D., MARSHALL A., GUNARATNE P., ANDERSON M.L., CREIGHTON C.J., XIN L., DEAVERS M., WONG K.-K. and RICHARDS J.S. (2011). Molecular and functional characteristics of ovarian surface epithelial cells transformed by KrasG12D and loss of Pten in a mouse model in vivo. Oncogene 30: 3522-3536. 
NICOL L., BISHOP S.C., PONG-WONG R., BENDIXEN C., HOLM L.E., RHIND S.M. and MCNEILLY A.S. (2009). Homozygosity for a single base-pair mutation in the oocyte-specific GDF9 gene results in sterility in Thoka sheep. Reproduction 138: 921-933.

NICHOLAS C.R., HASTON K.M. and PERA R.A.R. (2010). Intact fetal ovarian cord formation promotes mouse oocyte survival and development. BMCDev Biol10:2.

PETERS H. (1978). Folliculogenesis in mammals. In: The Vertebrate Ovary (Ed. R.E. Jones). Plenum Press, pp 121-144.

PEJOVIC T., YATES J.E., LIU H.Y. et al., (2006). Cytogenetic instability in ovarian epithelial cells from women at risk of ovarian cancer. Cancer Res 66: 9017-9025.

RABINOVICI J. and JAFFE R.B. (1990). Development and regulation of growth and differentiated function in human and subprimate fetal gonads. Endocr Rev 11: 532-557.

ROBERTSON D.M., PRUYSERS E. and JOBLING T. (2007). Inhibin as a diagnostic marker for ovarian cancer. Cancer Lett 249: 14-17.

RUGGIU M., SPEED R., TAGGART M., MCKAY S.J., KILANOWSKI F., SAUNDERS P., DORIN J. and COOKE H.J. (1997). The mouse Dazla gene encodes a cytoplasmic protein essential for gametogenesis. Nature 389: 73-77.

SAWYER H.R., SMITH P., HEATH D.A., JUENGEL J.L., WAKEFIELD S.T.J. and MCNATTY K.P. (2002). Formation of ovarian follicles during fetal development in sheep. Biol Reprod 66: 1134-1150.
SMITH P., OW.-S., CORRIGANK.A., SMITHT., LUNDYT., DAVISG.H. and MCNATTY K.P. (1997). Ovarian morphology and endocrine characteristics of female sheep fetuses that are heterozygous or homozygous for the Inverdale prolificacy gene. Biol Reprod 57: 1183-1192.

THOMPSON L.H. and HINZ J.M. (2009). Cellular and molecular consequences of defective Fanconi anemia proteins in replication-coupled DNA repair: mechanistic insights. Mutat Res 668: 54-72.

VANDERHYDEN B.C. (2005). Loss of ovarian function and the risk of ovarian cancer. Cell Tissue Res 322: 117-124.

VAUGHAN S., COWARD J.I., BAST R.C. et al., (2011). Rethinking ovarian cancer: recommendations for improving outcomes. Nature Rev 11: 719-725.

VAN WAGENEN G. and SIMPSON M.E. (Eds.) (1965). Embryology of the ovary and testis Homo sapiens and Macaca mulatta. Yale University Press, New Haven.

WANG X.-Z., ANDREASSEN P.R. and D'ANDREA A.D. (2004). Functional interaction of monoubiqutinated FANCD2 and BRCA2/FANCD1 in chromatin. Mol Cell Biol 24: 5850-5862.

WU X., CHEN L., BROWN C.A., YAN C. and MATZUK M.M. (2004). Interrelationship of growth differentiation factor 9 and inhibin in early folliculogenesis and ovarian tumorigenesis in mice. Mol Endocrinol 18: 1509-1519.

WYSHAM W.Z., MHAWECH-FAUCEGLIAP., LI H., HAYS L., SYRIAC S., SKREPNIK T., WRIGHT J., PANDE N., HOATLIN M. and PEJOVICT. (2012). BRCAness profile of sporadic ovarian cancer predicts disease recurrence. PLoS One 7: e30042. 


\section{Further Related Reading, published previously in the Int. J. Dev. Biol.}

Impaired meiotic competence in putative primordial germ cells produced from mouse embryonic stem cells Marianna Tedesco, Donatella Farini and Massimo De Felici Int. J. Dev. Biol. (2011) 55: 215-222

Differentiation of mouse primordial germ cells into female or male germ cells N Nakatsuji and S Chuma

Int. J. Dev. Biol. (2001) 45: 541-548

The meiotic specific synaptonemal complex protein SCP3 is expressed by female and male primordial germ cells of the mouse embryo

A D Di Carlo, G Travia and M De Felici

Int. J. Dev. Biol. (2000) 44: 241-244

In vitro germ cell differentiation during sex differentiation in a teleost fish Tohru Kobayashi

Int. J. Dev. Biol. (2010) 54: 105-111

Generation of germ-line chimera zebrafish using primordial germ cells isolated from cultured blastomeres and cryopreserved embryoids

Yutaka Kawakami, Rie Goto-Kazeto, Taiju Saito, Takafumi Fujimoto, Shogo Higaki, Yoshiyuki Takahashi, Katsutoshi Arai and Etsuro Yamaha

Int. J. Dev. Biol. (2010) 54: 1493-1501

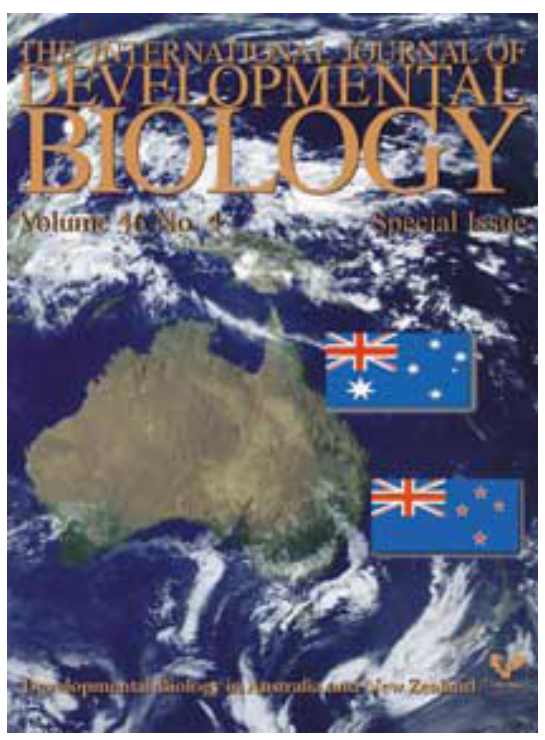

5 yr ISI Impact Factor $(2011)=2.959$

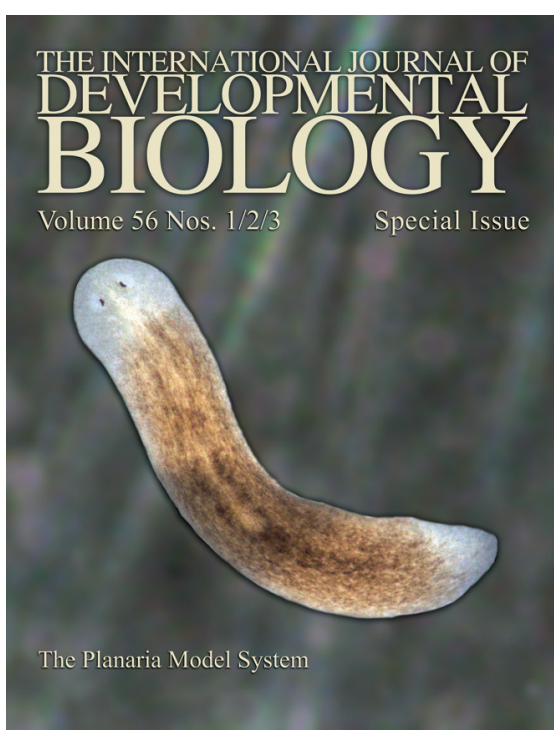

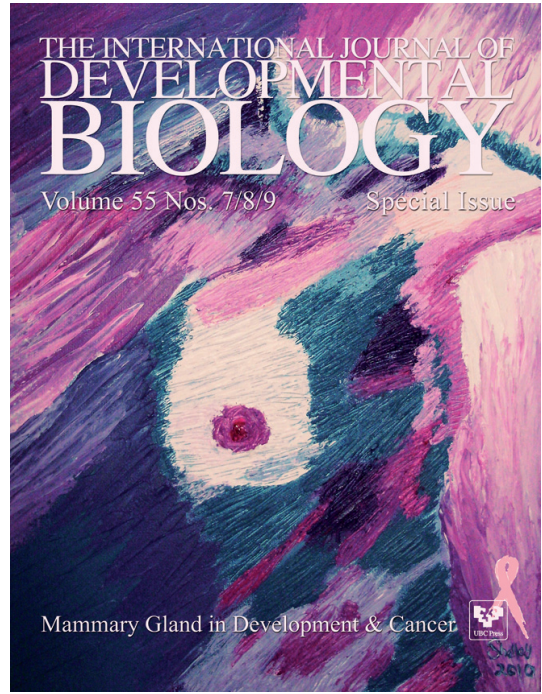

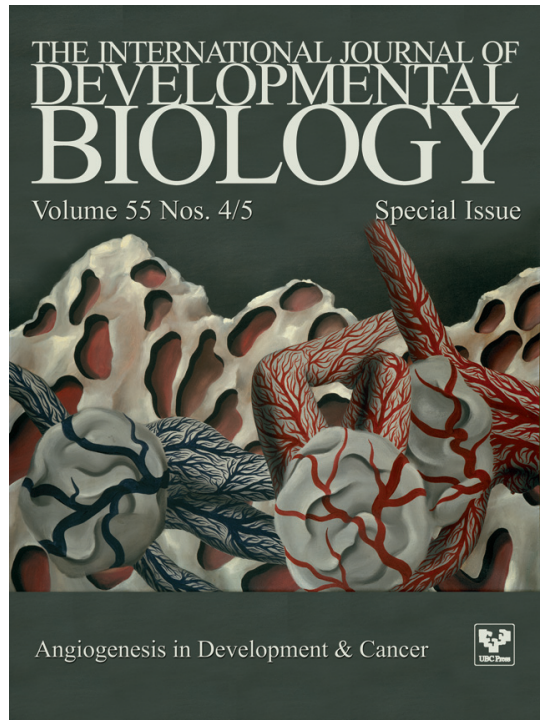

